\title{
External Democratization after War: Success and Failure
}

\author{
SONJA GRIMM
}

\begin{abstract}
In post-war societies external actors promote democracy within a broad framework of state- and nation-building, rule-of-law building, and economic development. But not all democracy promotion efforts succeed in an equal way. A closer look at cases of intervention and democratization since 1945 helps us to account for this variation. Cases of democratization can be differentiated according to their level of post-war socio-economic development, the level of social trust versus the level of inner-societal violence, the character of remaining stateness, the potential erosion of the nation, and the terms of peace. In order to explain the democratization successes of the post-World War II period on the one hand, and the apparent democratization failures of the 1990s and after 11 September 2001 on the other, the strategies external actors use in post-war transformation must be considered. Sometimes, external actors differ significantly in their ability and willingness to deal with the five issues mentioned above. Given differences in both structural conditions and actor engagement, external actors should be more careful when using some of the early democratization cases as blueprints for democracy promotion today.
\end{abstract}

Key words: democratization; promotion of democracy; external actors; war; intervention

\section{Introduction}

In the course of a civil war, a foreign military intervention, or military defeat in an inter-state war, a window of opportunity for democratic change can open and the restoration or the institutionalization of a democratic regime can become possible. From today's perspective, the early post-World War II cases of (re-)democratization of fascist regimes is a success story of external democratization. Germany, Austria, and Italy were forced by the war-winning allies to reform their political systems towards democracy and the rule of law. ${ }^{1}$ In Japan, the US military forces even imposed a democratic political system from scratch. ${ }^{2}$ In the aftermath of a world war that caused millions of deaths, large-scale starvation, and immense refugee flows all over Europe, these states were able to develop into full-fledged democracies - this despite the fact that the conditions seemed to be anything but advantageous for democracy.

Quite the opposite seems to be true for post-war transition to democracy since the beginning of the 1990s. After the collapse of the Soviet Union an international commitment to democracy and human rights emerged and set the context for the

Konstanzer Online-Publikations-System (KOPS URL: http://nbn-resolving.de/urn:nbn:de:bsz:352-185654 
international community of states and international non-state organizations to engage in democracy promotion in transformation countries. ${ }^{3}$ These transition processes were supported by external engagement through international financial and technical aid, expert advice, supervision of state-building, monitoring of elections and sometimes the offer of membership in attractive regional organizations. ${ }^{4}$ War-torn countries in Africa, Latin America, Southeast Europe, and the Middle East received extensive grants for state-building and democratization. ${ }^{5}$ Some countries were even temporarily administered by an international interim authority or a unilateral occupation regime with strong preferences for the introduction of norms and rules complying with international law and liberal economic standards. ${ }^{6}$ However, despite the external actors' keen interest in rapid democratization, most recent cases still struggle through deep socio-economic and ethno-religious conflicts and are stuck somewhere in the institutional transition process. According to the results of a study by Mixin Pei and Sarah Kasper, the consolidation of a full-fledged democratic political system in a war-torn country receiving US external support is mostly unlikely. ${ }^{7}$ An extended and more comprehensive tableau of cases considering several external actors engaging in major post-war reconstruction and democratization operations since 1945 does not present a more positive picture (see Table 1). So, the puzzle is: why were the early democratization processes of post-World War II states under occupation successful, while the success of democratization in recent cases of post-war transition seems unlikely despite massive foreign assistance?

To answer the question, this study will proceed as follows. To begin with, it presents an overview of the universe of cases that have been affected by post-war external democratization, evaluating success and failure of transition to democracy within a ten-year period. In the subsequent explanation of why some cases succeeded but others failed, a two-step analysis is employed. First, it differentiates cases by the structural conditions that affect the transition processes: the socio-economic situation after war and intervention, the existing level of stateness, the underlying minority and ethno-national conflicts, the level of societal trust, and the conditions of peace. Second, it compares the different strategies of external engagement - that is, how external actors deal with these conditions in order to promote democracy. As will become clear, external actors promote democracy in post-war societies within a wider framework of economic development, state-building, the promotion of the rule of law, as well as nation-building. However, the success of these strategies varies according to the prevalent structural conditions and according to local acceptance of external interference in domestic affairs.

\section{The Cases}

Obviously, each case included in the analysis has its own conflict history and path dependencies. Nevertheless, cases can be sorted according to the type of war or intervention they experience, and according to the strategies external actors engage in after the core military operation. According to these two criteria Wolfgang Merkel and the writer distinguish four modes of external democratization after war: enforcing democratization by enduring post-war occupation (mode 1); restoring an elected 
TABLE 1

SUCCESS AND FAILURE OF EXTERNAL DEMOCRATIZATION AFTER WAR

\begin{tabular}{|c|c|c|c|c|c|c|c|c|c|}
\hline \multirow[b]{2}{*}{$\begin{array}{l}\text { Mode of promoting } \\
\text { democracy }\end{array}$} & \multirow[b]{2}{*}{$\begin{array}{l}\text { Type of interim } \\
\text { administration }\end{array}$} & \multirow[b]{2}{*}{ Country } & \multirow[b]{2}{*}{$\begin{array}{l}\text { Height of external } \\
\text { presence }\end{array}$} & \multirow[b]{2}{*}{$\begin{array}{l}\text { Main external } \\
\text { military actor }\end{array}$} & \multicolumn{2}{|c|}{ Polity IV ${ }^{2}$} & \multicolumn{2}{|l|}{$\begin{array}{l}\text { Freedom } \\
\text { House }^{3}\end{array}$} & \multirow[b]{2}{*}{$\begin{array}{c}\text { Democracy }^{4} \\
\text { after } \\
10 \text { years }\end{array}$} \\
\hline & & & & & $\begin{array}{c}1 \text { year } \\
\text { before } \\
\text { intervention }\end{array}$ & $\begin{array}{l}10 \\
\text { years } \\
\text { after }\end{array}$ & $\begin{array}{c}1 \text { year before } \\
\text { intervention }\end{array}$ & $\begin{array}{l}10 \\
\text { years } \\
\text { after }\end{array}$ & \\
\hline \multirow{3}{*}{$\begin{array}{l}\text { Enforcing } \\
\text { democratization } \\
\text { by occupation }\end{array}$} & $\begin{array}{l}\text { Occupation/ } \\
\text { multilateral }\end{array}$ & Germany (West) & $1945-49$ & USA, GB, F & -9 & 10 & - & - & Yes \\
\hline & $\begin{array}{l}\text { administration } \\
\text { Occupation/ } \\
\text { multilateral } \\
\text { administration }\end{array}$ & Austria & $1945-52$ & Allies & $0^{5}$ & 10 & - & - & Yes \\
\hline & $\begin{array}{c}\text { Occupation/US } \\
\text { administration }\end{array}$ & Japan & $1945-52$ & USA & 1 & 10 & - & - & Yes \\
\hline \multirow[t]{4}{*}{$\begin{array}{l}\text { Restoring elected } \\
\text { government }\end{array}$} & $\begin{array}{l}\text { Local administration } \\
\text { with US } \\
\text { monitoring }\end{array}$ & Dominican Republic & $1965-66$ & USA & $0^{5}$ & -3 & - & 4,3 & No \\
\hline & $\begin{array}{l}\text { Local administration } \\
\text { with US } \\
\text { monitoring }\end{array}$ & Grenada & 1983 & USA & - & - & 7,5 & 1,2 & Yes \\
\hline & $\begin{array}{l}\text { Local administration } \\
\text { with US } \\
\text { monitoring }\end{array}$ & Panama & 1989 & USA & -8 & 9 & 6,5 & 1,2 & Yes \\
\hline & $\begin{array}{l}\text { Local administration } \\
\text { with US/UN } \\
\text { monitoring }\end{array}$ & Haiti & $1994-96$ & USA, UN & -7 & $-88^{6}$ & 7,7 & 4,5 & $?$ \\
\hline
\end{tabular}


TABLE 1

CONTINUED

\begin{tabular}{|c|c|c|c|c|c|c|c|c|c|}
\hline \multirow[b]{2}{*}{$\begin{array}{l}\text { Mode of promoting } \\
\text { democracy }\end{array}$} & \multirow[b]{2}{*}{$\begin{array}{l}\text { Type of interim } \\
\text { administration }\end{array}$} & \multirow[b]{2}{*}{ Country } & \multirow[b]{2}{*}{$\begin{array}{l}\text { Height of external } \\
\text { presence }\end{array}$} & \multirow[b]{2}{*}{$\begin{array}{l}\text { Main external } \\
\text { military actor }\end{array}$} & \multicolumn{2}{|c|}{ Polity $\mathrm{IV}^{2}$} & \multicolumn{2}{|c|}{$\begin{array}{l}\text { Freedom } \\
\text { House }^{3}\end{array}$} & \multirow[b]{2}{*}{$\begin{array}{c}\text { Democracy } \\
\text { after } \\
10 \text { years }\end{array}$} \\
\hline & & & & & $\begin{array}{c}1 \text { year } \\
\text { before } \\
\text { intervention }\end{array}$ & $\begin{array}{l}10 \\
\text { years } \\
\text { after }\end{array}$ & $\begin{array}{l}1 \text { year before } \\
\text { intervention }\end{array}$ & $\begin{array}{l}10 \\
\text { years } \\
\text { after }\end{array}$ & \\
\hline \multirow[t]{8}{*}{$\begin{array}{l}\text { Humanitarian } \\
\text { intervention and } \\
\text { democratization }\end{array}$} & $\begin{array}{l}\text { Local administration } \\
\text { with UN } \\
\text { supervision }\end{array}$ & Cambodia & $1991-93$ & UN & 1 & 2 & 7,7 & 6,5 & No \\
\hline & $\begin{array}{l}\text { Local administration } \\
\text { with UN } \\
\text { monitoring }\end{array}$ & Mozambique & $1992-94$ & UN & -6 & 6 & 6,4 & 3,4 & $?$ \\
\hline & $\begin{array}{l}\text { Local administration } \\
\text { with UN } \\
\text { monitoring }\end{array}$ & El Salvador & $1992-95$ & UN & 7 & 7 & 3,4 & 2,3 & Yes \\
\hline & $\begin{array}{l}\text { Local administration } \\
\text { with UN } \\
\text { monitoring }\end{array}$ & Guatemala & 1997 & UN & 8 & 8 & 3,4 & 3,4 & $?$ \\
\hline & $\begin{array}{l}\text { Local administration } \\
\text { with UN } \\
\text { monitoring }\end{array}$ & Sierra Leone & 1999 & GB; UN, ECOWAS & $0^{5}$ & 5 & 3,5 & 4,3 & $?$ \\
\hline & $\begin{array}{l}\text { NATO/EU/UN } \\
\text { administration, } \\
\text { High } \\
\text { Representative }\end{array}$ & Bosnia-Herzegovina & $1995-?$ & NATO & $0^{5}$ & $-66^{7}$ & 6,6 & 3,3 & $?$ \\
\hline & $\begin{array}{l}\text { NATO/EU/UN } \\
\text { administration }\end{array}$ & Kosovo $^{1}$ & $1999-?$ & NATO/UN & - & - & - & - & $?$ \\
\hline & UN administration & East Timor ${ }^{2}$ & $1999-2002$ & UN & - & 6 & - & 3,4 & $?$ \\
\hline
\end{tabular}




\begin{tabular}{|c|c|c|c|c|c|c|c|c|}
\hline \multirow[t]{2}{*}{$\begin{array}{l}\text { Democratic } \\
\text { intervention }\end{array}$} & $\begin{array}{l}\text { Local administration } \\
\text { with NATO/UN- } \\
\text { supervision } \\
\text { Occupation/US- }\end{array}$ & Afghanistan & 2001-? & USA, allies & -7 & $-66^{7}$ & 7,7 & 5.5 \\
\hline & $\begin{array}{l}\text { Uccupation/US- } \\
\text { administration }\end{array}$ & Iraq & $2003-?$ & USA, allies & & & & \\
\hline
\end{tabular}

Sources: Polity IV variable 'Polity2' 2005, available at http://www.cidcm.umd.edu/polity/data/showFiles.asp in section 'Polity IV Data Sets', registration required (accessed 15 Nov. 2007); Monty G. Marshall and Keith Jaggers, Polity IV Project. Political Regime Characteristics and Transitions, 1800-2002, Dataset Users Manual (Oct. 2005), available at http://www.cidcm.umd.edu/polity/data/showFiles.asp in section 'Polity IV Data Sets', registration required (accessed 19 Nov. 2007). Freedom House variables 'Political Rights, Civil Rights', 2007, http://www.freedomhouse.org/template.cfm?page=15 (accessed 15 Nov. 2007). Own research. Notes:

${ }^{1}$ Polity IV and Freedom House deliver no scores for non-sovereign territories. Territorial status of Kosovo not yet defined. East Timor gained independence in 2002 2 Polity IV 'Polity2' scores ten years after intervention. Scores available 1800-2004. For cases 1945-1993 scores ten years after intervention. For cases since 1995

scores for 2004.
${ }_{3}^{3}$ Freedom House, Political Rights, Civil Rights. Scores available 1973-2006. For cases 1973-1996 scores ten years after intervention. For cases since 1997 scores for 2006

${ }^{4}$ Polity IV rates democracy with at least 6 points (from 10). Freedom House calls a country 'free' (equals liberal democracy) with at least average score $25(1$ free 7 not Polity IV rates democracy with at least 6 points (from 10). Freedom House calls a country 'free' (equals ifbera democracy) with at least average score 2.5 (1 free. 7 not ree). If both indices rate the country over that score, democracy after ten years is 'yes', other whe 'n'. if the discordant, democracy after ten years is '?'.

terregnum or anarchy' (Marshall and Jaggers, Polity IV Project, Users' Manual, p. 16)

Variable 'Polity2' is not available. Polity variable ' $-88^{\prime}$ ' indicates 'cases of transition' (Marshall and Jaggers, Polity IV Project, Users' Manual, p. 16).

Variable 'Polity2' is not available. Polity variable ' -66 ' indicates 'cases of foreign interruption' (Marshall and Jaggers. Polity IV Project, Users' Manual, p. 16). 
government by military intervention (mode 2); intervening in ongoing massacres and civil war with military forces ('humanitarian intervention') and engaging in democratic institution-building in the thereafter reconstruction process (mode 3); and enforcing democracy on rogue states by 'democratic intervention' (mode 4). ${ }^{8}$ This classification will guide the analysis of structural conditions and external actors' behaviour.

In presenting the cases and evaluating their democratization success, the analysis follows the pragmatic approach of Stephan Finkel and his colleagues who use changes in the Polity IV and the Freedom House data set scores as a proxy for democratization. ${ }^{9}$ The state of democratic institutions as well as political and civil rights are compared as between one year before external intervention and ten years after external interveners leave. All cases of ongoing transition under external monitoring or supervision since the middle of the 1990s fall below the ten-year threshold. For these cases, Table 1 presents the latest scores available in the data sets.

Since 1945, I count 17 cases of external democratization after war, violent conflict or external military intervention. Six cases of external democracy promotion (West Germany, Japan, Austria, Grenada, Panama, Iraq) were effected by or followed an inter-state war, 11 cases followed an intra-state war (for an overview of the conflict types according to the common conflict data sets see Table 2). ${ }^{10}$ Applying our mode of war/intervention and democracy promotion typology, results in slightly different groupings.

In West Germany, Austria, Japan (mode 1) and Iraq (mode 4), the old regime collapsed because of a clear cut-military defeat. The winning party installed an occupying military regime and temporarily exercised executive, legislative, and judicial control in an interim administration. ${ }^{11}$ All occupying regimes tried to set out a democratization process by launching constitution making and democratic elections. ${ }^{12}$ These three cases of external democratization following World War II (mode 1) each achieved a full democracy score of ' 10 ' in Polity IV directly after the end of the occupying regime and kept it over the ten-year period (see Tab. 1). Given current civil strife and insurgency, an equal development in Iraq (mode 4) seems rather doubtful. ${ }^{13}$

In the case of Grenada (1983), Panama (1989) and the Dominican Republic (1965-1966), the US government tried to restore an overthrown elected government by military intervention (mode 2) ${ }^{14}$ During the Cold War, until the breakdown of the Soviet Union, US unilateral interventions in Latin American countries dominated the landscape of resolving intra-state political conflicts. With the military interventions in the Dominican Republic, the US intended to overthrow the military that opposed the democratically elected head of state; in the case of Grenada the US intervened to support the elected government in its fight against the opposition movement; and in the case of Panama the US intervened to secure the lives of Americans living on Panamanian territory and (more or less by the way) to support the opposition whose candidate won presidential elections. ${ }^{15}$ The operations in the Dominican Republic and Grenada were not followed by an aid programme for restructuring state institutions and promoting long-term democratization. In these and other countries, democracy promotion fell prey to higher ranked US priorities of economic 
prosperity and in particular national security. ${ }^{16}$ In Panama, US forces stayed for a few months, mainly to rebuild infrastructure and train the Panamanian military. ${ }^{17}$ While Panama and Grenada were able to use the intervention as a stimulus to democratic change, the Dominican Republic failed to democratize in the following ten-year period.

The end of the Cold War did not end the US influence on resolving internal political conflicts in Latin America. Its intervention in the intra-state conflict of Haiti (1994-1996) also falls within the group of democracy promotion by 'restoring an elected government' (mode 2). But in contrast to the cases of the Cold War period, the intervention was followed by a comprehensive peace-building strategy under the lead of the United Nations. ${ }^{18}$ Nevertheless, Haiti did not achieve even a minimal level of democracy in the ten-year period following intervention, as coded by Polity IV or Freedom House.

As demonstrated in the Haitian case, the end of the bipolar world changed the willingness of multilateral coalitions and international organizations to intervene militarily in conflict-prone societies. Not only unilateral, but also multilateral interventions became an option for conflict resolution in ongoing intra-state ethnic and political conflicts, genocide, and large-scale human-rights violations. Once on the ground, peacekeepers realized the necessity to engage more comprehensively in post-war reconstruction and democratization. The members of the UN Security Council gradually included state reconstruction and democratization in the missions' mandates (mode 3). The monitoring of elections in particular became a major tool of conflict resolution. ${ }^{19} \mathrm{In}$ addition, multilateral missions shaped the contents of peace agreements and included written plans for free and fair elections. They provided expert advice to local parties in war-shattered states during the implementation phase. Several international agencies like the World Bank or the International Monetary Fund (IMF) imposed conditions requiring states to undertake specific economic and political reforms in exchange for economic aid. And they even performed quasi-governmental functions such as the guarantee of public security by military and police force presence. ${ }^{20}$

In Mozambique, El Salvador, Haiti, Bosnia-Herzegovina, Guatemala, and Sierra Leone, the United Nations and its partner organizations combined peace-making and peace-building means to monitor the peace processes. ${ }^{21}$ The UN interim administration of Cambodia (1991-1993) served as a precursor to the UN protectorates in Kosovo (since 1999) and East Timor (1999-2002) where the UN fulfilled executive, legislative, and judicial tasks. ${ }^{22}$

Despite extensive external support, only four of the mode 3 cases of the 1990s show hopeful democratization outcomes. El Salvador clearly merits democratic credentials from Polity and Freedom House, based on its institutions and respect for civil and political rights. Mozambique, Guatemala, and East Timor just scrape by the democracy threshold proposed by the indices. Cambodia, Haiti, and Sierra Leone are far from being consolidated democracies. Bosnia-Herzegovina is stuck in institutional deadlock without having yet regained full national sovereignty and still depends on supervision by the High Representative; and Kosovo meanwhile is struggling with the question of its future territorial status, and therefore is not ranked in any of the indices (see Table 1). 
TABLE 2

WAR TYPES ACCORDING TO CONFLICT DATA SETS

\begin{tabular}{|c|c|c|c|c|}
\hline Mode of promoting democracy & Cases & $\mathrm{COW}^{2}$ (war) & $\begin{array}{l}\mathrm{PRIO}^{3} \text { (armed } \\
\text { conflict) }\end{array}$ & NEW LIST ${ }^{4}$ (war) \\
\hline $\begin{array}{l}\text { Enforcing democratization by } \\
\text { occupation }\end{array}$ & $\begin{array}{l}\text { Germany (West) } \\
\text { Japan } \\
\text { Austria }\end{array}$ & $\begin{array}{l}\text { Inter-state } \\
\text { Inter-state } \\
\text { Inter-state }\end{array}$ & $\begin{array}{l}- \\
- \\
-\end{array}$ & $\begin{array}{l}- \\
- \\
-\end{array}$ \\
\hline Restoring elected government & $\begin{array}{l}\text { Dominican } \\
\text { Republic } \\
\text { Grenada } \\
\text { Panama } \\
\text { Haiti } \\
\end{array}$ & $\begin{array}{c}\text { Intra-state } \\
- \\
- \\
- \\
\end{array}$ & $\begin{array}{l}\text { Internal } \\
\\
\text { Interstate } \\
\text { Interstate } \\
\text { Internal } \\
\end{array}$ & $\begin{array}{c}\text { Intra-state, with Belgian and US } \\
\text { intervention } \\
- \\
- \\
-\end{array}$ \\
\hline \multirow[t]{3}{*}{$\begin{array}{l}\text { Humanitarian intervention and } \\
\text { democratization }\end{array}$} & $\begin{array}{l}\text { Cambodia } \\
\text { Mozambique }\end{array}$ & $\begin{array}{l}\text { Intra-state } \\
\text { Intra-state }\end{array}$ & $\begin{array}{l}\text { Internal } \\
\text { Until } 1990 \\
\text { internationalized } \\
\text { internal, from } 1991 \\
\text { internal }\end{array}$ & $\begin{array}{l}\text { Intra-state } \\
\text { Intra-state }\end{array}$ \\
\hline & $\begin{array}{l}\text { El Salvador } \\
\text { Sierra Leone } \\
\text { Bosnia- } \\
\text { Herzegovina }\end{array}$ & $\begin{array}{l}\text { Intra-state } \\
\text { Intra-state } \\
\text { Intra-state }\end{array}$ & $\begin{array}{l}\text { Internal } \\
\text { Internal } \\
\text { Until } 1994 \\
\quad \text { internationalized } \\
\text { internal, from } 1994 \\
\quad \text { internal }\end{array}$ & $\begin{array}{l}\text { Intra-state } \\
\text { Sub-state } \\
\text { Sub-state, with NATO } \\
\quad \text { intervention }\end{array}$ \\
\hline & $\begin{array}{l}\text { Guatemala } \\
\text { Kosovo }\end{array}$ & $\begin{array}{c}\text { Intra-state } \\
-\end{array}$ & $\begin{array}{l}\text { Internal } \\
\text { Internationalized } \\
\quad \text { internal }\end{array}$ & $\begin{array}{l}\text { Intra-state } \\
\text { Intra-state, with NATO } \\
\text { intervention }\end{array}$ \\
\hline \multirow[t]{2}{*}{ Democratic intervention } & $\begin{array}{l}\text { East Timor } \\
\text { Afghanistan }\end{array}$ & $\begin{array}{l}- \\
-\end{array}$ & $\begin{array}{l}\text { Internal } \\
\text { Until } 2000 \text { internal. } \\
\quad \text { from } 2001 \\
\text { internationalized } \\
\text { internal }\end{array}$ & $\begin{array}{l}\text { Intra-state } \\
\text { Sub-state, with multinational } \\
\text { intervention }\end{array}$ \\
\hline & Iraq & - & Interstate & Interstate \\
\hline
\end{tabular}


Sources: Correlates of War (COW): Meredith Reid Sarkees, 'The Correlates of War Data on War: An Update to 1997', Conflict Management and Peace Science, Vol. 18 , No. 1 (2000), pp. 123-44; Melvin Small and J. David Singer, Resort to Arms: International and Civil Wars, 1816-1980 (Beverly Hills, CA: Sage Publications, 1982): Inter-State War Dataset Version 3.0 and Intra-State War Dataset Version 3.0, available at http://www.correlatesofwar.org/ (accessed 15 Nov. 2007).

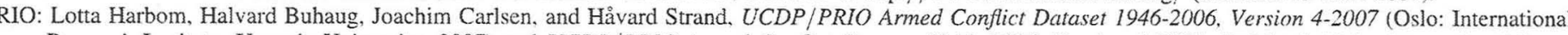

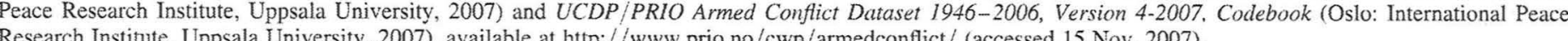

NEW LIST: Sven Chojnacki, New List of Wars, 1946-2003, Version 1.1 (July 2005), p. 5, available at http://www.polwiss.fu-berlin.de/frieden/pdf/warlist-1.1-72005.pdf

Notes:

For main external actors see Table 1.

Cow defines war as 'serious military conflicts between states (inter-state war), between states and non-state actors (extra-state war), and within states (intra-state war). This data set records such events over the 1816-1997 period' (http://www.correlatesofwar.org/, accessed 15 Nov. 2007). The threshold for war is '1,000 battle deaths for the whole conflict among military personal only' (Small and Singer, Resort to Arms, p. 55).

PRIO codes armed conflicts according to their intensity as '1. Minor: between 25 and 999 battle-related deaths in a given year. 2. War: at least 1,000 battle-related deaths in a given year" (Harbom et al., Codebook, p. 9). Four types of conflict are differentiated: '(1) Extrasystemic armed conflict occurs between a state and a non-state group outside its own territory... These conflicts are by definition territorial, since the government side is fighting to retain control of a territory outside the state system. (2) Interstate armed conflict occurs between two or more states. (3) Internal armed conflict occurs between the government of a state and one or more internal opposition group (s) without intervention from other states. (4) Internationalized internal armed conflict occurs between the government of a state and one or more internal opposition group(s) with intervention from other states (secondary parties) on one or both sides' (Harbom et al., Codebook, p. 9). It covers the period 1946-2006.

${ }^{4}$ Chojnacki defines war as '(1) inter-state wars between one or more internationally recognised states; (2) extra-state wars between a state and one or more non-state Chos (C) nised state, and (4) sub-state wars between non-state or non recognized quasi-state groups, whether within or across formal state borndaries. In stch cases, a functioning (Che

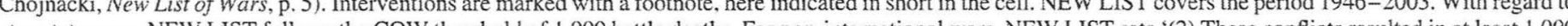
intestate wars, Ne WLIST follows he COW threshold of I, military or civilian deaths - attached by state or rebel forces - over their entire duration. (3) In or conflict killed at least 100 deaths per year on both sides' (Chojnacki, New List of Wars, p. 3 ). 
After the terrorist attacks of 11 September 2001, a multinational coalition under the lead of the US intervened both in Afghanistan and in Iraq as part of the 'war on terror' (mode 4). As a result of the military campaign against the al-Qaeda network, the Taliban regime and the regime of Saddam Hussein both collapsed. Massive international efforts have been undertaken to stabilize these countries and to pave the way for an Afghan and an Iraqi democracy. In both cases, the US government justified its military operations as necessary in the 'war on terror', so that repressive regimes that support terrorist networks can be overthrown and replaced with democratic regimes. In both Afghanistan and Iraq it is too early to judge the outcome of that undertaking, but in both cases the continuing lack of security has been detrimental to the progress toward democracy. ${ }^{23}$

From this brief empirical overview we can draw three conclusions. First, we can distinguish four historical periods of external democratization that largely coincide with our four modes of promoting democracy after war: (1) the post-World War II period with external occupation by the war winning allies and clear-cut democratization successes (mode 1); (2) the Cold War period with US intervention in government crises leading to mixed outcomes of either simple restoration of the elected government or failure in trying to do so (mode 2); (3) the post-1990 period with all intervention cases struggling to cope with domestic societal conflicts coupled with multinational efforts to mitigate these conflicts and implement a broad agenda of state- and democracy-building reforms (mode 3); ${ }^{24}$ and (4) the post-2001 period framed by the 'war on terror' with one case of multinational intervention in an ongoing sub-state conflict (Afghanistan) and one inter state-war with enforced regime change (Iraq) (mode 4).

Second, the success of external democratization depends on the type of war or conflict in each case. While all the inter-state war cases of the post-World War II period became clear-cut democratization successes, the picture of all inner- or substate war cases and cases of military intervention is mixed. None of the latter cases achieved a Polity IV score of ' 10 '. Only five countries achieved scores of ' 6 ' to ' 9 ' falling above the Polity IV democracy threshold.

Third, the differentiation between the two conflict types, inter-state war and intrastate war, cannot be sufficient to explain the different outcomes of democratization success or failure. As will be argued next, the mixed record of post-intra-state war democratization must depend on other structure- and actor-related factors.

\section{Explaining Success and Failure}

Terms like 'the hour zero' suggest that after war, actors can start their reform projects from a blank slate. ${ }^{25}$ But the collapse of the old regime as a result of military defeat does not erase prevalent path dependencies of structural disequilibria and societal cleavages, which may even have been intensified during war or violent conflict. The transition from war to peace can be better described as a process configured by actors' decisions and behaviour within a specific structural context experiencing 'complex dynamics, shifting agendas, and multiple interactions'. ${ }^{26}$ The following 
paragraphs examine the different structural conditions in the cases under scrutiny and the different strategies of external democratization after war.

\section{Structural Conditions}

Transition research has identified a number of analytically relevant structural conditions in transitional countries. These include, most notably, the level of socioeconomic development, the level of stateness, the existence of a nation, and potential minority conflicts. ${ }^{27}$ In war-torn countries the level of societal trust available after war and the terms of peace also play a crucial role in the chances of successful democratic transition. These conditions will be discussed with respect to the four modes of external democratization to explain how democratization cases are differently affected by their occurrence.

\section{Socio-economic Development}

Socio-economic welfare defines the distribution of power among the members of society. Unequal distribution of economic power results in unequal access to political power and unequal capability to express preferences in the political process. ${ }^{28} \mathrm{The}$ mode 1 cases had all been powerful economies before World War II. The conduct of inter-state war largely destroyed industrial facilities and private property. At the same time, the war evened out previously unequal distributions of economic wealth and left everyone struggling for survival. Furthermore, in contrast to Allied expectations, the economic infrastructure and private enterprises functioned relatively well after the war. ${ }^{29}$ In short, mode 1 cases were poor but not underdeveloped in 1945 . They managed to regain economic prosperity in a relatively short period and to allow fair political competition.

In contrast, mode 3 and 4 cases were affected by protracted economic and societal disparities. Highly disproportionate levels of income, often superimposed on ethnonationalist or religious cleavages, are major sources of violence when state institutions fail to moderate conflicting interests. ${ }^{30}$ In most of these cases, such conflicts persisted or even intensified in the course of becoming violent. War entrepreneurs are able to monopolize military or economic power while civilians suffer from arbitrary violence and hunger, and are often obliged to leave their homes. After the war, members of paternalistic networks try to continue profiting from welfare gains and privileges acquired in war, to secure their access to resources, and to transform military gains into political power. Mechanisms of clientelism, corporatism, patrimonialism, and corruption persist and hinder the spread of democratic norms and behaviour. $^{31}$

Some actors who gain power in war use radicalized conflict narratives to convince their supporters to participate in the war. Those actors are less likely to change their narratives in the course of preparing and conducting peace and may even try to reintroduce their radical ideas to the political agenda. Hence, nationalist issues appear to heavily influence the discourse on necessary reforms. Economically or militarily powerful actors playing the ethnic, religious, or ideological card can become spoilers of the peace process, especially if they have reason to fear a loss of their economic, social, and normative power position in peace negotiations and follow-up transition. ${ }^{32}$ 
Recent developments in Bosnia-Herzegovina, Kosovo, Iraq, and Afghanistan are typical examples.

\section{Stateness}

A central prerequisite for democratization after war are functioning state structures. A well-established state offers rational management of individual and collective needs, creates reliable rule of law procedures, constitutes a legitimate monopoly of force, and controls the territory effectively. ${ }^{33}$ But during war and intervention, the normal rules of a legitimate monopoly of force, the avoidance of a security vacuum, the guarantee of security, and the establishment of a legitimate monopoly of force all come under major challenge.

Mode 1 cases in particular suffered from completely delegitimized regimes and bureaucracies whose members had to be identified and punished. At the same time, mode 1 cases could rely on a long tradition of functioning and stable state structures with rational bureaucracies. ${ }^{34}$ With this prior experience in effectively administering the countries, the Allies could rebuild civil administrations in a short period of time and introduce democratic principles of political organization.

Most of the mode 3 and 4 cases could not rely on prior experience with a stable state. Even worse, intra-state wars contributed to the erosion of existent state structures and mostly caused their failure. ${ }^{35}$ Accordingly, mode 3 and mode 4 cases suffered from a lack of well-trained experts and corrupt instead of functioning rational bureaucracies. They could not rely on military and police forces capable of securing order, or on courts able to impartially impede criminals and dispense justice. But ongoing insurgencies, varieties of civil unrest, and communal discontent cannot be moderated without state institutions. ${ }^{36}$ As a tool of conflict resolution, state-building has recently received special external attention. The idea is to combine security for both former combatants and refugees. The former need guarantees against retaliatory violence committed by their adversaries after demobilization and disarmament and a chance to re-integrate into civilian life if they cannot join the new security forces. ${ }^{37}$ The latter need guarantees for safe return, reintegration into societal and working life as well as compensation for past injustices. ${ }^{38}$ Thus the need for rapid conflict resolution and the satisfaction of contradictory individual preferences places a heavy burden on the main actors of transition.

\section{Minority Conflicts and Nation-building}

Nation is here understood as a group of individuals with a sense of belonging to one political community based on shared history or identity. ${ }^{39}$ Such a political community is the basis for accepting majority decisions and for regulating the fair distribution of goods and services. While the nation in mode 1 cases was not contested, all mode 3 and mode 4 cases and Haiti (mode 2) struggled through protracted political, ethnonational, religious or socio-economic conflicts that called into question the very existence of a nation.

The sense of belonging to one nation is especially eroded in multi-ethnic, multireligious, multi-linguistic states. Cultural traditions, customs, symbols, rituals, and historical narratives become contested. The erosion of the nation's coherence can 
escalate into violent conflict and war. ${ }^{40}$ Such nation failure is a typical source of intra-state wars and becomes a major obstacle for state reconstruction and democratization after war, as demonstrated in the Latin American countries, in the Balkans, and in the Middle East.

\section{Social Trust and Inner-societal Violence}

Trust is a necessary precondition for organizing interests and negotiating consensus, both in turn essential for democracy. ${ }^{41}$ In addition to socio-economic disparities and the erosion of a nation, the mere experience of war, of arbitrary violence, torture and rape, displacement, and dispossession can destroy trust. ${ }^{42}$ The absence of innersocietal trust especially affects the transition of the mode 3 cases. These post-conflict societies suffered either from arbitrary violence by the governing authorities or violence between different ethnic groups that sometimes escalated to ethnic cleansing or genocide. Under such circumstances trust is at best available in families, clans, tribes, ethnic or religious groups, but not beyond kinship or ideological boarders. This societal split poses the permanent danger of renewed violence, or the struggle for autonomy rights or even secession. Mostly, there is no functioning civil society that could bridge these cleavages, ${ }^{43}$ making it difficult to build the consensus required for a peace process. Without trust, each participating group has no other option than to expect deception by their counterparts during peace negotiations and democratization. ${ }^{44}$ Mode 4 cases show a similar low trust profile. In these cases, long-term repression and brutal dictatorship destroyed the fundaments of inner-societal trust. The military operations within the 'war on terror', for example, reinforced existing mistrust, provoked insurgency against the external occupiers, and escalated to assaults against members of other ethnic or religious groups.

The failure to moderate conflict heightens the risk of a renewed outbreak of violence in the form of incidents incited by ethnic, religious, or ideological issues, verbal provocation, or single assaults that escalate into widespread violence, as seen in Haiti (mode 2), Sierra Leone, Bosnia-Herzegovina, Kosovo (mode 3), and even more so in Afghanistan and Iraq (mode 4).

\section{Conditions of Peace}

Classic wars, in Kalevi Holsti's terms, have a clear-cut end: 'Following the declarations of war, armed combat led either to stalemate or, more often, to a decisive military defeat in a single battle or a short series of battles. The defeated party then agreed to a formal armistice and sued for peace. ${ }^{45}$ Mode 1 cases present an even clearer picture: the war-winning allies did not need to negotiate a peace agreement, but could demand the signing of an unconditional surrender. ${ }^{46}$ They could install occupying regimes to stabilize the war-affected countries and to guarantee that the World War II aggressor states would not regain their destructive power. The frontline was clear: winning parties could declare the rules of peace; defeated parties had to accept them. The success of the Allies was not contested by those defeated. The clear-cut military success made the defeated amenable to externally enforced reform projects. 
In mode 2 cases external interveners fulfilled their promise to reinstall the elected government. The terminology of war 'winners' and 'losers' did not play a role or even affect political development after the withdrawal of US troops. With the exception of Haiti, long-term military protection for the reinstalled elected government or even the supervision of a peace treaty was not necessary.

The conflict lines in mode 3 and 4 cases have rarely been so obvious. Almost none of the military interventions or the intra-state wars have had such clear-cut endings. In most of the mode 3 cases facing an intra-state war, the need to guarantee security and to overcome the security dilemma overshadowed peace negotiations. Without effective security guarantees, normally provided by a third party, the warring parties could hardly agree on a peace treaty. ${ }^{47}$ But monitoring by a third party such as the United Nations or European Union does not mean that all relevant groups automatically support the final decisions and agree to play according to the new rules. The pressure to keep peace provoked radical minorities to use violence in order to be heard and therefore to become spoilers of the peace process, as, for example, in Bosnia or Kosovo.

In mode 4 cases the external interventions themselves were highly contested. Both regimes collapsed due to military intervention carried out as part of the 'war on terror'. Negotiations on a peace agreement seemed unnecessary. But both cases entailed a political process including massive external pressure to democratize the political regime. In the Afghan case, the international community and local representatives negotiated the political future in the Bonn process. ${ }^{48}$ As a consequence of this process, the military intervention was followed by a local interim administration and accompanied by a constitution-drafting process under intensive international supervision. ${ }^{49}$ The highly contested military operation against the Hussein regime was followed by a no less contested US military occupation. US officials also set up a constitution-drafting process and meanwhile administered the country with less local ownership. The precipitous transfer of sovereignty back to Iraqi authorities could not conceal the consequences of a brutal 35-year dictatorship: religious and socio-economic conflicts broke open after the regime's collapse, ${ }^{50}$ and no effective alternative authority could be built up in the short period of time and under the conditions of an occupation seen as illegitimate. The collapse of the state structures revealed that a new state would have to be built and this would require more resources and expertise than originally assumed. ${ }^{51}$

\section{Scope of Reforms}

\section{External Democratization Strategies}

Successfully terminating a democratization process in a war-torn society means dealing with the structural challenges described in the previous section. Obviously, it is a complex task. It requires dealing with the unfavourable structural conditions following warfare, with the loss of capable personnel who are able, willing, and moderate enough to shoulder the peace process, and with the unintended consequences of democratization itself. ${ }^{52}$ It calls for opportunities for post-war reconstruction, 
economic development, societal reconciliation, and political transformation. It demands anticipating well in advance what the society in trouble could possibly need in five or ten years, and requires a democratization framework that is flexible enough for adaptation to specific circumstances and unexpected events. Actors willing to democratize a post-war country must deal with fast developments in some sectors and delayed reforms in other sectors.

External actors must engage in roughly five sectors that have to be transformed or reformed in post-conflict societies; namely, humanitarian first aid and welfare, stateness, the rule of law, the political regime, and the political community. These transformations run over three transitional stages; namely. stabilization, institutionalization, and consolidation. For a successful completion of democratization, each sector needs the implementation of major reforms in each transitional period (Table 3). A brief overview of the reforms supported by external actors will clarify the scope of reform in post-war societies.

\section{Welfare}

The welfare sector sets the conditions for personal well-being. It should at least secure a minimum income and provide for the fair distribution of societal wealth. Societies that experienced war and military intervention are often characterized by economic decay, by high rates of socio-economic disparity and unequal distribution of economic welfare ${ }^{53}$ as well as a parallel economy of illegal activities like drug-, weapon-, and human trafficking. ${ }^{54}$ Beyond humanitarian first aid during and immediately after war, economic reconstruction entails the reconstruction of infrastructure and production facilities, the return and reintegration of refugees, the regulation of property rights, and the building of a tax system. Mechanisms to ensure fair access to resources and welfare gains have to be set up. Furthermore, economic development requires the general advancement of education in order to improve the populations' literacy rates and to educate skilful workers, executives, and specialists.

\section{Stateness}

To build a functioning state, reforms must achieve the physical protection of all citizens and the establishment of a legitimate monopoly of force. That means, first and foremost, external control over a ceasefire or peace accord, including a temporary curfew. Further important steps are the demobilization and disarmament of combatants and the rebuilding and training of police and military forces to achieve a stable and secure environment for further transition to democracy. ${ }^{55}$ Donors argue that former combatants should be reintegrated into the new security forces only when they receive training on how to use police or military power while respecting human rights standards, democratic rules, and all citizens, regardless of their socioeconomic, ethnic, or religious background. If they cannot be integrated in such programmes, former combatants must be at least guaranteed subsistence in the civil economic sector. ${ }^{56}$ Furthermore, a monopoly of force includes a regime of control over the security forces and clear-cut rules for the civil-military relationship. External actors must support the establishment of commonly accepted law as an output of a legitimate decision-making procedure. Obviously, the functioning of the monopoly of 
TABLE 3

EXTERNAL DEMOCRATIZATION AFTER WAR AND VIOLENT CONFLICT

\begin{tabular}{|c|c|c|c|}
\hline $\begin{array}{l}\text { Stages } \\
\text { Sectors }\end{array}$ & Stabilization & Institutionalization & Consolidation \\
\hline Welfare & $\begin{array}{l}\text { Humanitarian aid; } \\
\text { control of major } \\
\text { industries and } \\
\text { resources }\end{array}$ & $\begin{array}{l}\text { Building of infrastructure, } \\
\text { regulation for property } \\
\text { rights, reintegration of } \\
\text { combatants in economy, } \\
\text { tax system, currency } \\
\text { reform, development } \\
\text { programs }\end{array}$ & $\begin{array}{l}\text { Consolidation of economic } \\
\text { growth, social justice, just } \\
\text { distribution of welfare }\end{array}$ \\
\hline Stateness & $\begin{array}{l}\text { Control of armed } \\
\text { groups, } \\
\text { disarmament of } \\
\text { combatants, } \\
\text { demobilization }\end{array}$ & $\begin{array}{l}\text { Building of legitimate } \\
\text { monopoly of use of force, } \\
\text { training of military and } \\
\text { policy. Building of } \\
\text { effective civil } \\
\text { administration, capacity- } \\
\text { building }\end{array}$ & $\begin{array}{l}\text { Consolidation of transparent } \\
\text { civil-military relationship, } \\
\text { external and internal } \\
\text { security, consolidation of } \\
\text { transparent and effective } \\
\text { bureaucracy. }\end{array}$ \\
\hline Rule of law & $\begin{array}{l}\text { Control of judiciary, } \\
\text { interim legislature }\end{array}$ & $\begin{array}{l}\text { Building of courts, training of } \\
\text { judges, lawyers, } \\
\text { prosecutors; investigation } \\
\text { of war criminals }\end{array}$ & $\begin{array}{l}\text { Exercise of full judicial } \\
\text { power. Consolidated } \\
\text { respect of civil and } \\
\text { political rights, } \\
\text { independent and impartial } \\
\text { judiciary, fair trials }\end{array}$ \\
\hline Political regime & $\begin{array}{l}\text { Interim legislature, } \\
\text { selection of } \\
\text { representatives for } \\
\text { constituent } \\
\text { assembly }\end{array}$ & $\begin{array}{l}\text { Building of administration, } \\
\text { constitution-building, } \\
\text { including negotiations on } \\
\text { power-sharing } \\
\text { mechanisms and minority } \\
\text { rights, founding elections, } \\
\text { establishment of political } \\
\text { institutions according to } \\
\text { constitution }\end{array}$ & $\begin{array}{l}\text { Exercise of full executive and } \\
\text { legislative power. } \\
\text { Consolidation of political } \\
\text { institutions, continued } \\
\text { democratic decision- } \\
\text { making, periodic free and } \\
\text { fair elections with peaceful } \\
\text { transfer of governmental } \\
\text { power }\end{array}$ \\
\hline Political community & $\begin{array}{l}\text { Protection of civilians, } \\
\text { control of media }\end{array}$ & $\begin{array}{l}\text { Return of refugees and } \\
\text { reintegration; construction } \\
\text { of plural media system; } \\
\text { voter education }\end{array}$ & $\begin{array}{l}\text { Reconciliation, solving/ } \\
\text { moderation of ethnical and } \\
\text { socio-cultural/economic } \\
\text { conflicts, building of trust, } \\
\text { transitional justice. } \\
\text { Consolidation of civic } \\
\text { culture }\end{array}$ \\
\hline
\end{tabular}

Source: Author's research. Scheme adapted from Juan J. Linz and Alfred Stepan, Problems of Democratic Transition and Consolidation. Southern Europe, South America, and Post-Communist Europe (Baltimore, MD: The Johns Hopkins University Press, 1996), p. 14; Wolfgang Merkel, Systemtransformation (Opladen: Leske + Budrich, 1999), p. 122.

force and the guarantee of security do not only depend on the mere physical establishment of police and military troops, police offices and military camps, but also on the formal institutionalization of an effective bureaucracy. These organs can only be based on clear rules, which provide a means of control and a means for judging illegal behaviour. The work is done when a well-ordered monopoly of force is established that is counterbalanced by democratic control and stands the test of avoiding the outbreak of violence among former enemies. 
Rule of Law

The rule of law provides the fundamentals for the protection of individual civil and political rights, the checks and balances for a fair and legitimate decision-making process, and the judicial limitations on executive and legislative power. As a result, a stable rule of law system offers a mechanism for resolving conflicts through fair trials and the guarantee of individual and minority rights. The building of the justice sector requires as a preliminary step the building of an independent judiciary that provides an effective arena for fair negotiation of any societal dispute, especially in the heated post-war atmosphere. It must be complemented by a criminal justice system that punishes acts of violence in a neutral and independent way. External actors must ensure that the building of courts, and the training of judges, attorneys, lawyers, and police officers. They also must help establish clear rules and procedure for investigating, prosecuting and judging criminal activities.

Respect for the rule of law also affects the public sector. It is necessary to establish a civil administration based on the rule of law in order to enable a transparent, fair and corruption-free distribution of public goods. ${ }^{57}$ Therefore, the enhancement of administrative capacities in the form of personal skills, transfer of knowledge, and technical facilities is important.

Increasingly, external actors also engage in the prosecution of past abuses and other forms of transitional justice. ${ }^{58}$ An important step is to find a common narrative of past events in order to expose the underlying cleavages and sources of violence. The creation of a historic record that includes the testimony of all warring parties contributes substantially to the formation of a political community. Compensation, restitution, and rehabilitation acknowledge war victims' pain, compensate their material loss, and deter officials from further atrocities. ${ }^{59}$

\section{Political Regime}

A political regime should provide commonly accepted procedures for decisionmaking. A democratic political regime should be based on general consent over procedures of decision-making and implementation. These procedures should be fair, transparent, and open to individual demands, and they should respect the will of the people. In post-war societies, democracy requires the willingness and ability of all relevant actors to play the democratic game according to new rules without relapsing into violence. All major and minor groups should be represented, and able to participate in political decision-making. ${ }^{60}$ In order to achieve democratic behaviour in a political process, external actors supervise the drafting of a constitution. They monitor the preparation and conduct of democratic elections. ${ }^{61}$ Democratic elections require democratic parties, or at least political groups that are eligible and willing, to accept an open democratic competition. ${ }^{62}$ Some external actors, therefore, support the development of a representative party system. ${ }^{63}$

Beyond political competition, external support includes the building of a plural media system that can inform the public of decisions and also report on failures in the different sectors of reform and provide a platform for general debate. The training of voters and elites in political and civil rights underpins the external will to promote reforms. ${ }^{64}$ 


\section{Political Community}

The creation of a political community is another difficult task in a post-war context. Without an at least minimal sense of belonging, individual members will hardly accept the decisions made within a political system. Police officers from different societal groups will hardly accept treating every citizen as equal, judges will hardly act in a neutral, impartial way, employers will hardly hire employees from another ethnic group, and media will hardly refrain from hate campaigns against minorities. However, building trust in a war-torn society is a long-term process traversing several generations. It entails not only agreement on national symbols like the flag or anthem, but also the definition of who can become a citizen, who is allowed to vote, and who can be elected. ${ }^{65}$ Forming a political community requires long-term conflict resolution, a transitional justice process, justly distributed welfare, and freedom from political, socio-economic, or religious discrimination. At best, citizens ought, eventually, to perceive themselves as individuals with equal rights and as members of a political community. At worst, different groups may end up striving for comprehensive autonomy rights or even territorial separation. External actors have long hesitated to engage in nation-building in the sense of constructing a political community, by means such as re-education programmes. But, as they recognize that successful democratization cannot afford to ignore community-building, external actors are increasingly engaging in political education. ${ }^{66}$

The extent of external engagement in the five sectors discussed varies over the set of cases. In mode 1 and mode 4 cases, external actors engaged comprehensively in all five sectors during the interim period until a local government took over executive and legislative responsibility. Mode 2 cases resulted only in a slight US engagement in stabilizing the monopoly of force and in supporting the elected government but without pushing for political reforms. Mode 2 interventions did not affect the welfare regime, rule of law or even long-term democratic reforms in the political regime. Mode 3 interventions show the biggest variety of external engagement after military intervention (see Table 1). In Mozambique, El Salvador, Guatemala, and Sierra Leone, external actors under the direction of the United Nations monitored the peace agreements and intervened slightly in the reform process over the five sectors, but they focused on the issues of rule of law and stateness. ${ }^{67}$ In Cambodia the UN mission supervised the peace process and temporarily co-administered the territory with local authorities. Their mandate was especially focused on questions concerning stateness and on conducting democratic elections. ${ }^{68}$ In East Timor and Kosovo external actors under the direction of the United Nations fulfilled (and in Kosovo still fulfil) executive, legislative, and judicial functions. They used their presence to launch reform projects in all five sectors. ${ }^{69}$ The same is true for the international presence in Bosnia-Herzegovina, whose High Representative possesses extensive rights to supervise and intervene in legislation. Here too, external actors engage in all five sectors of reforms. ${ }^{70}$

In principal, external actors are well advised to address all five reform areas because they are highly interconnected. Reform in one sector is often dependent on the reform success in one or more other sectors. For example, a lack of physical and rule of law security can hinder foreign investment, thereby retarding economic 
development, which reduces welfare gains, which then in turn undermines the legitimacy of the political system. A political system trapped in an institutional stand-off fails to regulate property rights, which prevents refugees from returning and this, in turn, stops the inflow of skilled workers needed for economic reconstruction. An ineffective judiciary, to further illustrate, is not able to prosecute past atrocities and, therefore, fails to contribute to the establishment of a past narrative and hinders the creation of a political community. Obviously, there are also positive reciprocal effects of peace-, state-, nation- and democracy-building and economic development. Progress in one sector can lead to success in another, but postponement in one sector can become an obstacle for all others.

External actors are well aware of this interconnectedness, nevertheless they do not always engage in all five sectors to the same extent in all cases. This is either because they do not want to, or because they are not allowed to. In mode 1 cases the populations of the defeated nations did not dare to resist foreign occupation and had no choice but to accept it, though grudgingly. The population in mode 2 cases also had fewer means to oppose US power. But external democratization in mode 3 cases legally and literally cannot be driven without internal consent. When internal actors are able and willing to take responsibility for the transformation of the political system, they accept only moderate support from the outside. In cases such as Mozambique, El Salvador, and Guatemala, external actors 'only' had to support local authorities and to monitor state- and democracy-building. In those cases where internal actors were at odds with each other and massive ethno-political conflicts endangered the peace process (Cambodia, Bosnia-Herzegovina) or where the non-existence of self-sustaining state structures made external involvement necessary (East Timor, Kosovo), external actors were required to engage comprehensively, as supervisors or interim administrators. In Afghanistan (mode 4) external actors refrained from a supervisory or interim administrative role, not least because they were reluctant to shoulder once more the responsibility of state-building from scratch in a post-conflict society.

All these projects of external democratization formally took place with the consent of local actors. Although, beyond a signature on an internationally binding contract, the consent of relevant elites is a relative good. Elite consent can evaporate if external actors fail to deliver expected goods and services and if local actors do not feel respected and understood by interim administrators or democracy promoters. ${ }^{71}$ It can also evaporate if external and internal actors differ substantially on preferred strategies, the time horizon set for achieving the defined aims, or the legitimacy gained by either moral supremacy or output-oriented reform success.

It is even worse if local non-elite support for external intervention vanishes into thin air as it has in Iraq. The Iraqis did not experience a military defeat on the scale of World War II and did not undergo a gradual process of reconciliation such as made West Germans amenable to the Allied occupation. Under the Ba'ath regime, the non-existence of the rule of law, along with arbitrary detention, imprisonment, torture and executions, were part of daily life for most non-privileged Iraqis, whether Sunni or Shi' ia. As a consequence, they felt themselves to be the victims of a brutal regime and were unwilling to live again with a regime that imposed restrictions on individual liberty. Meanwhile, the US Coalition Provisional Authority (CPA) 
had no adequate strategy to manage the outbreak of violent conflicts and to secure peace in the country. Particularly in the early period of the fall of Baghdad, poor preparation, scant knowledge of the country, and a lack of sensitivity to social and cultural customs contributed to the failure of the CPA, which lost its credibility as a benevolent liberator. ${ }^{72}$ Political demands by people freed from tyranny but confronted with a new non-legitimate, poorly performing occupation authority were manifested violently. ${ }^{73}$ The US forces set up a process of democratic institution-building, constitution-drafting, and nation-wide elections, but failed to find a power-sharing arrangement among Sunni, Shi'ia and Kurdish factions. ${ }^{74}$

Obviously, neither the light 'footprint strategy' (Afghanistan) nor the forced 'occupation strategy' (Iraq) assured the desired success. Given current evidence, none of the mode 4 democratic interventions succeeded in securing peace, building up stable state institutions, and effectively controlling the whole territory. In the Afghan case the local authorities were not able to assert control; in the Iraqi case, neither the US troops nor the Iraqi government have been able to secure a monopoly of force.

Enforcing democratization by occupation, as in mode 1 cases, is in today's world doomed to failure. Instead, external actors are expected to respect the principles of partnership and local ownership. In the complex situation of intra-state wars the difficulty, however, is to identify democracy-prone actors and to find reliable partners whom externals can support in implementing democratic reforms. After a period of exclusive and uncontested military occupation after 1945, the Allies relied on untainted and equally democracy-prone actors for the restructuring of the political systems. They excluded adherents of the old regime as far as possible but accepted them if they could contribute technical knowledge. ${ }^{75}$ In mode 3 and with the extending intra-state violence in mode 4 cases, it is very difficult to decide who is untainted by violence and who could support democratization. Few relevant elites seem to be willing to support boundless external democratization projects. ${ }^{76}$

\section{Conclusions}

External democratization has followed a variety of different conflicts, such as foreign military intervention in an ongoing government crisis to support the threatened democratically elected regime, an intervention in an ongoing civil war in whose course external actors supported democratization, or a military campaign to force a democratic regime change. Democratization processes have sometimes been initiated by external actors and sometimes just welcomed as a positive side-effect of military intervention. When external actors actively support democratization, their activities are embedded in a post-war environment and must cope with the reconstruction of failed or destroyed state structures, the transformation of war into peace economies, the promotion of market liberalization, the reorganization of the civil and military administrations, and nation-building. This comprehensive political, economic, and sometimes even societal transformation ought to aim at preventing a renewed outbreak of violence and enabling relevant political actors to resolve their disputes in 
a peaceful way, rather than on the battleground. ${ }^{77}$ But not many external actors succeed with their democratization strategies as desired.

The analysis of structural challenges in mode 1,2, 3 and 4 cases reveals substantial differences in structural conditions that make an environment more or less favourable for democratization. In particular, unresolved security dilemmas, state failure, protracted minority conflicts, and a permanent loss of societal trust become significant obstacles to external democratization. If external actors fail to win the hearts and minds of relevant elites and people on the ground, their engagement in democratization will hardly succeed - regardless of whether external actors choose a strategy that has been successfully field-tested in another context.

Whether external involvement in political reconstruction after war is accepted by locals depends both on the degree of legitimacy for the war or the intervention and on the success of the intervention in terms of achieving substantial progress in the political reform process. In the aftermath of an inter-state war or an intra-state war that resulted in the defeat of a completely delegitimized authoritarian regime, local actors are probably more willing to accept external involvement in internal affairs if the externals can offer incentives for democratization and mitigate conflicts that would otherwise not be solved.

These distinctions question efforts to use some of the early democratization successes as blueprints for contemporary democracy promotion. Commentators, politicians, and analysts tend to use the historic examples of the major post-war reconstruction operations in West Germany, Japan, and Austria to claim a right or at least the capability to promote democracy by waging war or by military intervention. These operations indeed led to successful long-term democratization, but only under the special post-World War II structural conditions, which turned out to be surprisingly favourable for re-democratization. Nevertheless, these structural conditions are not generalizable to all post-conflict situations, and therefore, taking these cases as a blueprint for future democratization efforts is not to be recommended.

\section{ACKNOWLEDGEMENTS}

The author would like to thank Wolfgang Merkel for his helpful comments on an earlier version of this text, Daniela Leitner for her research assistance, Lora Viola and Gudrun Mouna for their technical support.

\section{NOTES}

1. Richard L. Merritt, Democracy Imposed. US Occupation Policy and the German Public, 1945-1949 (New Haven, CT: Yale University Press, 1995); Peter Merkl, 'Allied Strategies of Effecting Political Change and Their Reception in Occupied Germany', Public Policy, Vol. 17 (1968), pp. 59-103; John D. Montgomery, Forced to be Free. The Artificial Revolution in Germany and Japan (Chicago, IL: University of Chicago Press, 1957).

2. John W. Dower, Embracing Defeat: Japan in the Wake of World War II (New York: W. W. Norton, 2002).

3. Thomas M. Franck, 'The Emerging Right to Democratic Governance', American Journal of International Law, Vol. 86, No. 1 (1992), pp. 46-91; Thomas M. Franck, 'The Democratic Entitlement', University of Richmond Law Review, Vol. 29, No. 1 (1994-1995), pp. 1-39; Peter J. Schraeder, 'The State of the Art in International Democracy Promotion: Results of a Joint European-North American Research Network', Democratization, Vol. 10, No. 2 (2003), pp. 21-44; United Nations, A More 
Secure World: Our Shared Responsibility. Report of the High-level Panel on Threats, Challenges and Change (New York: United Nations Department of Public Information, 2004).

4. Peter Burnell (ed.), Democracy Assistance. International Co-operation for Democratization (London Frank Cass, 2000); Thomas Carothers, Aiding Democracy Abroad. The Learning Curve (Washington, DC: Brookings Institution Press, 1999).

5. Steven E. Finkel, Aníbal Pérez-Linán, and Mitchell A. Seligson, The Effects of US Foreign Assistance on Democracy Building, 1990-2003, available at www.pitt.edu/ politics/democracy/ democracy.html (accessed 15 Nov. 2007).

6. Roland Paris, 'International Peacebuilding and the "Mission Civilisatrice", Review of International Studies, Vol. 28, No. 4 (2002), p. 637-56; Sabine Kurtenbach, 'Why is Liberal Peace-building So Difficult? Some Lessons form Central America', Working Paper No. 59, GIGA, Berlin, 2007.

7. Minxin Pei, and Sara Kasper, Lessons from the Past: The American Record on Nation Building. Policy Brief No.24 (Washington, DC: Carnegie Endowment for International Peace, 2003), p.4, available at http://www.carnegieendowment.org/files/Policybrief24.pdf (accessed 15 Nov. 2007).

8. For detailed definition of the four modes of external democratization see Wolfgang Merkel and Sonja Grimm in this special issue.

9. Finkel, Pérez-Linán, and Seligson (note 5).

10. The definitions of sub-state and intra-state war rely on the definitions used by COW, PRIO or NEW LIST. Please find them in the annex of Table 2.

11. Rüdiger Wolfrum, 'Iraq - from Belligerent Occupation to Iraqi Exercise of Sovereignty: Foreign Power versus International Community Interference', in Armin von Bogdandy, Rüdiger Wolfrum, and Christiane E. Philipp (eds), Max Planck Yearbook of United Nations Law. Volume 9. 2005 (Leiden: Martinus Nijhoff Publishers, 2005), pp. 1-45; L. Elaine Halchin, 'The Coalition Provisional Authority (CPA): Origin, Characteristics, and Institutional Authorities' (Washington, DC: CRS Report for Congress, 2005); Montgomery (note 1); Roy Licklider, 'The American Way of State Building: Germany, Japan, Somalia and Panama', Small Wars and Insurgencies, Vol. 10, No. 3 (1999), pp. $82-115$.

12. Jeffrey M. Diefendorf, Axel Frohn, and Hermann-Josef Rupieper (eds), American Policy and the Reconstruction of West Germany, 1945-1955 (Cambridge, MA: Cambridge University Press, 2004); Katia Papagianni, 'State Building and Transitional Politics in Iraq: The Perils of a Top-down Transition', International Studies Perspectives, Vol. 8, No. 3 (2007), pp. 253-71.

13. Anthony H. Cordesman, 'Iraq's Evolving Insurgency and the Risk of Civil War', CSIS Report, Washington DC, 2006; International Crisis Group, 'The Next Iraqi War? Sectarianism and Civil Conflict', Middle East Report No. 52 (2006), Brussels.

14. Contrary to the common conflict data sets, we categorize the US engagement as a military intervention in an intra-state conflict. In the conflict data sets, the US intervention in Grenada (1983) and Panama (1989) are coded as inter-state wars, the conflict in the Dominican Republic (1965-1966) is coded as an intra-state war.

15. Jonathan Hartlyn, 'The Dominican Republic: The Legacy of Intermittent Engagement', in Abraham F. Lowenthal (ed.), Exporting Democracy. The United States and Latin America. Case Studies (Baltimore, MD: The Johns Hopkins University Press, 1991), pp. 53-92; Laurence Whitehead, 'The Imposition of Democracy', in Lowenthal, idem, pp. 234-60.

16. Abraham F. Lowenthal, 'The United States and Latin American Democracy: Learning from History', in Lowenthal (note 15), pp. 261-83.

17. Licklider (note 11), p.93.

18. Julia Leininger, 'Democracy and UN Peace-Keeping - Conflict Resolution through State-Building and Democracy Promotion in Haiti', in Armin von Bogdandy and Rüdiger Wolfrum (eds), Max Planck Yearbook of United Nations Law, Volume 10, 2006 (Leiden: Martinus Nijhoff Publishers, 2006), pp. 465-530.

19. Ben Reilly, Democracy in Divided Societies. Electoral Engineering for Conflict Management (Cambridge, MA: Cambridge University Press, 2001).

20. Paris (note 6), pp. 642-45

21. United Nations, 'Report of the Panel on United Nations Peace Operations' (The Brahimi Report), A/55/305-S/2000/809, 21 Aug. 2000, available at http://www.un.org/peace/reports/peace operations/ (accessed 11 Nov. 2005).

22. For Cambodia and East Timor, see Aurel Croissant in this collection. For Kosovo see Oisín Tansey, 'Democratization without a State: Democratic Regime-building in Kosovo', Democratization, Vol 14 , No. 1 (2007), pp. 129-50.

23. For an actual state of transition see Astri Suhrke in this special issue. 
24. Haiti also falls into this period as a case initially aimed to 'restore an elected government' (mode 2) but then extended by a long-term UN mission that made efforts towards state- and democracy-building. At present, these cases mostly do not achieve the ten-year threshold for evaluation; but as a trend, some of them are well on the way to being democratization successes while others stagnate or even go backwards.

25. Uta Gerhard, Soziologie der Stunde Null. Zur Gesellschaftskonzeption des amerikanischen Besatzungsregimes in Deutschland 1944-1945/46 (Frankfurt: Suhrkamp, 2005). Uta Gerhard uses the term 'zero hour' in the book title and signifies the beginning of reconstruction in Germany after the unconditional surrender in 1945. The term is commonly used in academic debates on this topic.

26. Laurence Whitehead, Democratization. Theory and Experience (Oxford: Oxford University Press, 2002), p. 36.

27. Aurel Croissant, Von der Transition zur Defekten Demokratie (Wiesbaden: Westdeutscher Verlag, 2002), p. 53-63; Wolfgang Merkel, Hans-Jürgen Puhle, Aurel Croissant, Claudia Eicher, and Peter Thiery, Defekte Demokratie. Band 1: Theorie (Opladen: Leske + Budrich, 2003), p. 200-38; J. Linz and A. Stepan, “'Stateness", Nationalism, and Democratization', in Juan Linz, and Alfred Stepan (eds), Problems of Democratic Transitions and Consolidation (Baltimore, MD: The Johns Hopkins University Press, 1996), pp. 16-37; Adam Przeworski, Michael Alvarez, José Antonio Cheibub, and Fernando Limongi, 'What Makes Democracy Endure?' Journal of Democracy, Vol. 7, No. 1 (1996), pp. 39-55.

28. Aurel Croissant, Von der Transition zur defekten Demokratie (Wiesbaden: Westdeutscher Verlag, 2002), p. 56.

29. Werner Abelshauser, 'Kriegswirtschaft und Wirtschaftswunder. Deutschlands wirtschaftliche Mobilisierung für den Zweiten Weltkrieg und die Folgen für die Nachkriegszeit', Vierteljahresheft für Zeitgeschichte, Vol. 47, No. 4 (1999), pp. 503-28.

30. David Keen, 'Incentives and Disincentives for Violence', in Mats R. Berdal and David M. Malone (eds), Greed and Grievance. Economic Agendas in Civil Wars (Boulder, CO: Lynne Rienner, 2000), pp. 19-42.

31. Michael Pugh, 'Transformation in the Political Economy of Bosnia since Dayton', International Peacekeeping, Vol. 12, No. 3 (2005), pp. 450-51.

32. Heiko Nitzschke and Kaysie Studdard, 'The Legacies of War Economies: Challenges and Options for Peacemaking and Peacebuilding', International Peacekeeping, Vol. 12, No. 2 (2005), pp. 222-39.

33. Neil J. Kritz, 'The Rule of Law in the Postconflict Phase. Building a Stable Peace', in Chester A. Crocker, Fen Osler Hampson, and Pamela R. Aall (eds), Managing Global Chaos: Sources of and Responses to International Conflict (Washington, DC: United States Institute of Peace Press, 1996), p. 603.

34. Norbert Frei, Adenauer's Germany and the Nazi Past (New York: Columbia University Press, 2002).

35. Robert I. Rotberg (ed.), When States Fail. Causes and Consequences (Princeton, NJ: Princeton University Press, 2004); Ludgera Klemp, and Adolf. Kloke-Lesch, 'Taking on Responsibility in Situations of Fragile Statehood and Poor Government Performance', in BMZ [Federal Ministry for Economic Cooperation and Development] (ed.), Transforming Fragile States - Examples of Practical Experience (Baden-Baden: Nomos, 2007), pp. 20-31.

36. Rotberg (note 35), pp. 5-10.

37. Barbara F. Walter, Committing to Peace. The Successful Settlement of Civil Wars (Princeton, NJ: Princeton University Press, 2002), p. 160.

38. R. Caplan, International Governance of War-Torn Territories. Rule and Reconstruction (Oxford: Oxford University Press), pp. 68-9.

39. Linz and Stepan (note 27), pp. 16-20.

40. Armin von Bogdandy, Stefan Häussler, Felix Hanschmann, and Raphael Utz, 'State-building, NationBuilding, and Constitutional Politics in Post-Conflict Situations: Conceptual Clarifications and an Appraisal of Different Approaches', in Armin von Bogdandy, Rüdiger Wolfrum, and Christiane E. Philipp (eds), Max Planck Yearbook of United Nations Law. Volume 9. 2005 (Leiden: Martinus Nijhoff Publishers, 2005), pp. 579-613.

41. Robert Putnam, 'Bowling Alone: America's Declining Social Capital', Journal of Democracy, Vol. 6, No. 1 (1995), pp. 65-78.

42. Lorraine Elliott, 'The United Nations and Social Reconstruction in Disrupted States', in William Maley, Charles Sampford, and Ramesh Thakur (eds), From Civil Strife to Civil Society. Civil and Military Resonsibilities in Disrupted States (Tokyo: United Nations University Press, 2003), pp. $257-78$.

43. Daniel N. Posner, 'Civil Society and the Reconstruction of Failed States' (note 35), pp. 237-55. 
44. Donald Rothchild, 'Settlement Terms and Postagreement Stability', in John Stephen Stedman, Donald Rothchild, and Elizabeth M. Cousens (eds), Ending Civil Wars. The Implementation of Peace Agreements (Boulder, CO: Lynne Rienner, 2002), pp. 117-38.

45. Kalevi J. Holsti, The State, War and the State of War (Cambridge, MA: Cambridge University Press, 1996), p. 19.

46. Ibid., p. 35

47. Walter (note 37), p. 9

48. On the lack of legitimacy see Astri Suhrke in this special issue.

49. Burnett R. Rubin, 'Crafting a Constitution for Afghanistan', Journal of Democracy, Vol. 15, No. 3 (2004), pp. 5-19.

50. Marion Farouk-Sluglett, and Peter Sluglett, Iraq since 1958. From Revolution to Dictatorship (London: I. B. Tauris, 2003), p. 300.

51. Toby Dodge, 'Iraq: The Contradictions of Exogenous State-building in Historical Perspective', Third World Quarterly, Vol. 27, No. 1 (2006), pp. 187-200.

52. Anna Jarstad, and Tim Sisk (eds), From War to Democracy (Cambridge, MA: Cambridge University Press, forthcoming 2008).

53. Heiko Nitzschke, and Kaysie Studdard, 'The Legacies of War Economies: Challenges and Options for Peacemaking and Peacebuilding', International Peacekeeping, Vol. 12, No. 2 (2005), pp. 222-39; Klaus Schlichte, 'Profiteure und Verlierer von Bürgerkriegen: Die soziale Ökonomie der Gewalt', in Werner Ruf (ed.), Politische Ökonomie der Gewalt. Staatszerfall und die Privatisierung von Gewalt und Krieg (Opladen: Leske + Budrich, 2003), pp. 124-43.

54. Achim Wennmann, 'Resourcing the Recurrence of Intrastate Conflict: Parallel Economies and Their Implications for Peacebuilding', Security Dialogue, Vol. 36, No. 4 (2005), pp. 479-94; Pugh (note $31)$, pp. 448-62.

55. Caplan (note 38), pp. 45-67.

56. Samuel M. Makinda, 'Disarmament and Reintergration of Combatants', in William Maley, Charles Sampford, and Ramesh Thakur (eds), From Civil Strife to Civil Society. Civil and Military Responsibilities in disrupted States (Tokyo: United Nations University Press, 2003), pp. 309-26; Joanna Spear, 'Disarmament and Demobilization', in John Stephen Stedman, Donald Rothchild, and Elizabeth M. Cousens (eds), Ending Civil Wars. The Implementation of Peace Agreements (Boulder, CO: Lynne Rienner, 2002), pp. 141-82.

57. Kritz (note 33), pp. 587-606.

58. See Marc Arenhövel in this special issue.

59. Kritz (note 33), p. 599.

60. Donald Rothchild and Phillip G. Roeder, 'Power Sharing as an Impediment to Peace and Democracy', in Phillip G. Roeder, and Donald Rothchild (eds), Sustainable Peace: Power and Democracy After Civil Wars (Cornell, NY: Cornell University Press, 2005), pp. 29-50.

61. Reilly (note 19), pp. 12-14.

62. Carl Gershman, 'Democracy Promotion: the Relationship of Political Parties and Civil Society', Democratization, Vol. 11, No. 3 (2004), pp. 27-35

63. Carrie Manning, 'Party-building on the Heels of War: El Salvador, Bosnia, Kosovo and Mozambique', Democratization, Vol. 14, No .2 (2007), pp. 253-72

64. Krishna Kumar, 'International Assistance to Promote Independent Media in Transition and PostConflict Societies', Democratization, Vol. 13, No. 4 (2006), pp. 652-67.

65. Linz and Stepan (note 27), pp. 16-37.

66. Lucy Taylor, 'Textbook Citizens: Education for Democracy and Political Culture in El Salvador', Democratization, Vol. 6, No. 3 (1999), pp. 62-83; Steve E. Finkel, 'Can Democracy be Taught?', Journal of Democracy, Vol. 14, No. 4 (2003), pp. 137-51.

67. David M. Law, 'Conclusion: Security Sector Reform in Post-Conflict Settings', International Peacekeeping, Vol. 13, No. 1 (2006), pp. 113-123; Jeremy Ginifer, 'The Challenge of the Security Sector and Security Reform Processes in Democratic Transitions: The Case of Sierra Leone', Democratization, Vol. 13, No. 5 (2006), pp. 791-810.

68. See Aurel Croissant in this collection.

69. Caplan (note 38), pp. 45-158.

70. David Chandler, Bosnia. Faking Democracy After Dayton (London: Pluto Press, 1999).

71. Simon Chesterman, 'Building Democracy through Benevolent Autocracy: Consultation and Accountability in UN Transitional Administrations', in Edward Newman, and Roland Rich (eds), The UN Role in Promoting Democracy. Between Ideals and Reality (Tokyo: United Nations University Press, 2004), pp. 86-112. 
72. Adeed Dawisha, 'Iraq: Setbacks, Advances, Prospects', Journal of Democracy, Vol. 15, No. 1 (2004), pp. 5-20.

73. Farouk-Sluglett and Sluglett (note 50), p. 305.

74. Philipp Dann and Zaid Al-Ali, 'The Internationalized "Pouvoir Constituant" - Constitution Making and External Influence in Iraq, Sudan and East Timor', in Armin von Bogdandy and Rüdiger Wolfrum (eds), Max Planck Yearbook of United Nations Law, Vol. 10 (Leiden: Martinus Nijhoff Publishers, 2006), pp. 423-63; Papagianni (note 12).

75. John H. Herz, 'Denazification and Related Policies', in John H. Herz (ed.), From Dictatorship to Democracy. Coping with the Legacies of Authoritarianism and Totalitarianism (Westport, CT: Greenwood Press, 1982), pp. 15-38.

76. Roy Licklider, 'Obstacles to Peace Settlements', in Chester A. Crocker, Fen Osler Hampson, and Pamela Aall (eds), Turbulent Peace. The Challenges of Managing International Conflict (Washington, DC: United States Institute of Peace Press, 2003), pp. 697-718.

77. Krishna Kumar, and Jeroen de Zeeuw, 'Democracy Assistance to Postconflict Socities', in Jeroen de Zeeuw, and Krishna Kumar (eds), Promoting Democracy in Postconflict Socities (Boulder, CO: Lynne Rienner, 2006), pp. 1-21.

Manuscript accepted for publication December 2007

Address for correspondence: Sonja Grimm, M.A., Social Science Research Center Berlin (WZB), Reichpietschufer 50, D-10785 Berlin, Germany. E-mail: grimm@wzb.eu 